\title{
Tritium transfer between sea and atmosphere in the English Channel (North Cotentin and Bay of Seine)
}

\author{
D. Maro ${ }^{1}$, L. Tenailleau ${ }^{2}$, M. Fontugne ${ }^{3}$, P. Germain ${ }^{1}$, D. Hébert ${ }^{1}$ \\ and M. Rozet ${ }^{1}$ \\ ${ }^{1}$ Institut de Radioprotection et de Sûreté Nucléaire, Laboratoire de Radioécologie de \\ Cherbourg-Octeville, 50130 Cherbourg-Octeville, France \\ ${ }^{2}$ Marine Nationale, Groupe d'Études Atomiques, BP. 34, 50115 Cherbourg Naval, France \\ ${ }^{3}$ Laboratoire des Sciences du Climat et de l'Environnement, UMR 1572-CEA/CNRS, \\ Domaine du CNRS, 91198 Gif-sur-Yvette, France
}

\begin{abstract}
Oceans, seas, estuaries and rivers represent a vast sink for many substances of anthropic origin (metals, radionuclides, etc...). Depending on their chemical form, artificial radionuclides discharged into the sea by the nuclear industry can be carried onto land in marine aerosols, as well as by degassing seawater as is the case for tritium $\left({ }^{3} \mathrm{H}\right)$ or for radiocarbon $\left({ }^{14} \mathrm{C}\right)$. Three oceanographic cruises in the English Channel: TE-SEA, TRANSAT 1 and 2 have been performed on R.V. "Côtes de la Manche" to quantify the flux of ${ }^{3} \mathrm{H}$ in gaseous form, from the sea into the atmosphere, following particular discharge into the sea from the COGEMA spent fuel reprocessing plant at La Hague (North West France). During cruises, the maximum concentration measured in the air was $10.6 \mathrm{~Bq} \cdot \mathrm{L}^{-1}$, which is distinctly higher than the background of $1 \mathrm{~Bq} . \mathrm{L}^{-1}$ thus demonstrating the transfer of ${ }^{3} \mathrm{H}$ between water and atmosphere. The mean flux of ${ }^{3} \mathrm{H}$ between the water and the atmosphere, calculated during these cruises was $2.410^{7} \mathrm{~Bq} \cdot \mathrm{km}^{-2} \cdot \mathrm{d}^{-1}$. For the Seine Bay area $\left(4400 \mathrm{~km}^{2}\right)$ this flux represents $39 \mathrm{TBq} \cdot \mathrm{yr}^{-1}$ and hence less than $0.3 \%$ of ${ }^{3} \mathrm{H}$ discharged into the ocean from the COGEMA spent fuel reprocessing plant at La Hague.
\end{abstract}

\section{INTRODUCTION}

Oceans, seas, estuaries and rivers represent a vast sink for many substances of anthropic origin (metals, radionuclides, etc...). Depending on their chemical form, artificial radionuclides discharged into the sea by the nuclear industry can be carried onto land in marine aerosols, as well as by degassing seawater as is the case for tritium $\left({ }^{3} \mathrm{H}\right)$ or for radiocarbon $\left({ }^{14} \mathrm{C}\right)[1,2]$. Knowledge of these exchanges should lead to quantification of the radioactivity discharged into the atmosphere then transferred into the soil and plants and to man. In June 2000 and February and August 2002, the Laboratoire de Radioécologie de Cherbourg-Octeville (LRC, Cherbourg, France) in association with the Laboratoire des Sciences du Climat et de l'Environnement (LSCE, Gif sur Yvette, France) and the French Navy Groupe d'Etudes Atomiques (GEA, Cherbourg, France), carried out oceanographic cruises TE-SEA, TRANSAT 1 and 2 on the R.V. "Côtes de la Manche", to quantify the flux of gaseous ${ }^{3} \mathrm{H}$ from the sea into the atmosphere, between the point of discharge into the ocean from the COGEMA spent fuel reprocessing plant at La Hague and the Seine estuary. This paper presents the results of these cruises. 


\section{EQUIPMENT AND METHOD}

\subsection{Method}

Discharge into the ocean from the COGEMA spent fuel reprocessing plant at La Hague (Nord Cotentin, France) is the main source of ${ }^{3} \mathrm{H}$ in the English Channel [3]. For example, in 2002, this plant discharged $1.210^{16} \mathrm{~Bq} \cdot \mathrm{yr}^{-1}$ of ${ }^{3} \mathrm{H}$ into the sea and during the same year, atmospheric discharge was $6.310^{13}$ Bq. $\mathrm{yr}^{-1}$ of ${ }^{3} \mathrm{H}[4]$.

To evaluate the transfer of ${ }^{3} \mathrm{H}$ between water and atmosphere due to discharge into the sea by COGEMA La Hague, the flux of water vapour $\left(\mathrm{L}^{\mathrm{m}} \mathrm{m}^{-2} \cdot \mathrm{d}^{-1}\right)$ is calculated first, using Rohwer's formula [5]:

$$
\Phi\left(\mathrm{H}_{2} \mathrm{O}\right)=0.372\left(1-0.000374 \mathrm{P}_{\mathrm{a}}\right)\left(1+0.6 \mathrm{~V}_{\mathrm{w}}\right)\left(\mathrm{e}_{\mathrm{s}}-\mathrm{e}_{\mathrm{a}}\right)
$$

where:

$\Phi\left(\mathrm{H}_{2} \mathrm{O}\right)$ : Flux of water vapour $\left(\mathrm{L} \cdot \mathrm{m}^{-2} \cdot \mathrm{d}^{-1}\right)$,

$\mathrm{P}_{\mathrm{a}}$ : Atmospheric pressure (mbar),

$\mathrm{V}_{\mathrm{w}}$ : Wind speed $\left(\mathrm{m} . \mathrm{s}^{-1}\right)$,

$\mathrm{e}_{\mathrm{s}}$ : Saturated vapour pressure (mbar),

$\mathrm{e}_{\mathrm{a}}$ : Vapour pressure in the atmosphere (mbar).

Then, knowing the concentration of ${ }^{3} \mathrm{H}$ in the water, the flux of ${ }^{3} \mathrm{H}\left(\mathrm{Bq} \cdot \mathrm{m}^{-2} \cdot \mathrm{d}^{-1}\right)$ is determined using equation 2 :

$$
\Phi\left({ }^{3} \mathrm{H}_{2} \mathrm{O}\right)=\Phi\left(\mathrm{H}_{2} \mathrm{O}\right)\left[{ }^{3} \mathrm{Hw}\right]
$$

where:

$\Phi\left({ }^{3} \mathrm{H}_{2} \mathrm{O}\right)$ : Flux of ${ }^{3} \mathrm{H}$ between water and atmosphere $\left(\mathrm{Bq} \cdot \mathrm{m}^{-2} \cdot \mathrm{d}^{-1}\right)$,

$\left[{ }^{3} \mathrm{Hw}\right]$ : Concentration of ${ }^{3} \mathrm{H}$ in the water (Bq. $\left.{ }^{-1}\right)$.

\subsection{Sampling of seawater and air}

In 2000 and 2002, three oceanographic cruises were carried out with the INSU/CNRS Oceanographic Vessel "Côtes de la Manche" (figure 1) between 1 and 4 June 2000 (TE_SEA) and between the 24 and 28 February 2002 (TRANSAT 1) and 27 to 31 August 2002 (TRANSAT 2).

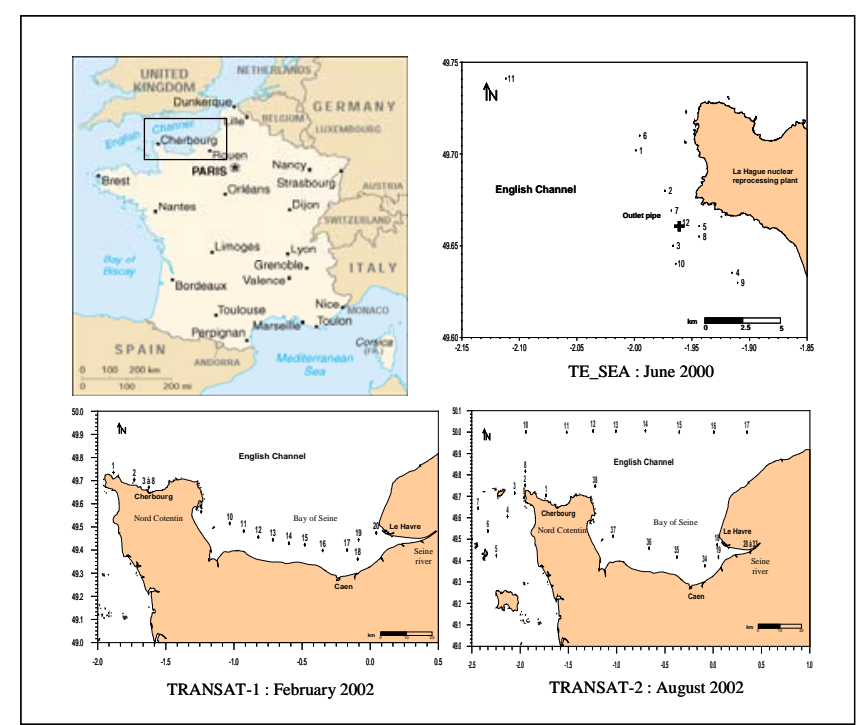

Figure 1. Location of sampling stations during TE-SEA, TRANSAT 1 and TRANSAT 2. 
The sampling periods reflect roughly the different meteorological patterns encountered during the year.

To avoid being under the atmospheric plume of the COGEMA La Hague plant, samples were taken upwind of the plant. During the cruises, close to COGEMA La Hague $(<50 \mathrm{~km})$, the activity of krypton $85\left({ }^{85} \mathrm{Kr}\right)$, a gas discharged by the plant into the atmosphere at the same time as ${ }^{3} \mathrm{H}$, was also measured continuously at one second intervals in order to verify the presence of atmospheric plume. The presence of ${ }^{85} \mathrm{Kr}$ discharged from the plant stack was detected immediately [6]. Samples for measuring ${ }^{3} \mathrm{H}$ in the air and seawater were therefore taken when the influence of the plant plume was undetectable.

Seawater was sampled after filtration at $0.45 \mu \mathrm{m}$ on the surface, in one litre polyethylene flasks.

The water vapour was condensed on a cold trap (PREVAIR system) developed specifically by IRSN (LRC) for this study in association with the French Navy (GEA). This sampling system allows the limit of detection to be lowered when measuring ${ }^{3} \mathrm{H}$ by a factor of 3000 compared with sampling systems using bubble tubes. This sampling, which takes about fifteen minutes, was performed two metres above the surface of the water.

Water temperature and salinity were measured with a Seabird SBE 19-03 probe. Air temperature, humidity, atmospheric pressure, wind speed and direction were measured using the "Côtes de La Manche" meteorological station (Young equipment).

\subsection{Measurement of ${ }^{3} \mathbf{H}$}

The seawater was purified by distillation to eliminate any radionuclides which could interfere with measuring ${ }^{3} \mathrm{H}$. The distilled seawater samples and water vapour samples from the air were mixed with a scintillating liquid in a standard metering flask before being transferred to a liquid scintillation counter for measurement. Measurements were made in the French Navy's low background laboratory at Cherbourg (Roule Laboratory).

\section{RESULTS AND DISCUSSION}

\subsection{Concentrations of ${ }^{3} \mathrm{H}$ in seawater and atmospheric water vapour}

The concentrations of ${ }^{3} \mathrm{H}$ in the seawater and atmospheric water vapour measured during the TE-SEA and TRANSAT 1 and 2 cruises are presented in figures 2 to 4 .

The mean concentrations measured in seawater were $14.8 \mathrm{~Bq} . \mathrm{L}^{-1}$ (maximum 20.9 Bq. $\mathrm{L}^{-1}$ ) during TE-SEA, 5.7 Bq.L $\mathrm{L}^{-1}$ (maximum 13.3 Bq. $\mathrm{L}^{-1}$ ) during TRANSAT 1 and $4.5 \mathrm{~Bq} . \mathrm{L}^{-1}$ (maximum 6.4 Bq. $\mathrm{L}^{-1}$ ) during TRANSAT 2. In comparison with the background in ${ }^{3} \mathrm{H}$, around $0.15 \mathrm{~Bq} . \mathrm{L}^{-1}$ at the entrance to the Channel, these measurements indicate industrial seawater labelling by mainly the COGEMA La Hague spent fuel reprocessing plant [7]. For the same points, the mean concentrations measured in atmospheric water vapour were $7.0 \mathrm{~Bq} . \mathrm{L}^{-1}$ (maximum $10.1 \mathrm{~Bq} . \mathrm{L}^{-1}$ ) during TE-SEA, $2.8 \mathrm{~Bq} . \mathrm{L}^{-1}$ (maximum 4.8 Bq. $\mathrm{L}^{-1}$ ) during TRANSAT 1 and 2.4 Bq. $\mathrm{L}^{-1}$ (maximum 3.8 Bq. $\mathrm{L}^{-1}$ ) during TRANSAT 2. In comparison with the ${ }^{3} \mathrm{H}$ background, below $1.0 \mathrm{~Bq} . \mathrm{L}^{-1}$ in air, these measurements indicate air labelling [3]. Since the samples were taken upwind, outside the atmospheric plume from the COGEMA La Hague plant, these results demonstrate that ${ }^{3} \mathrm{H}$ is transferred from the water into the atmosphere by evaporating seawater.

The highest concentrations in the air were measured during the TE-SEA cruise in an area close to the COGEMA La Hague plant ocean discharge point. In general, for all the cruises, the evolution of concentrations in the air follows the evolution of concentrations in water. The observed differences are due to different meteorological conditions at the time, wind speed and air hygrometry. 


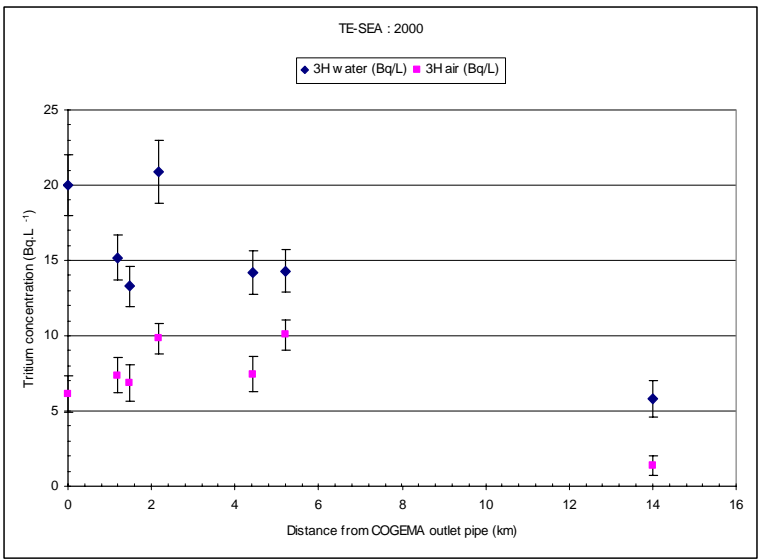

Figure 2. Variation of ${ }^{3} \mathrm{H}$ activities (Bq. $\mathrm{L}^{-1}$ ) in surface seawater and air versus distance from COGEMA outlet pipe during TE-SEA cruise.

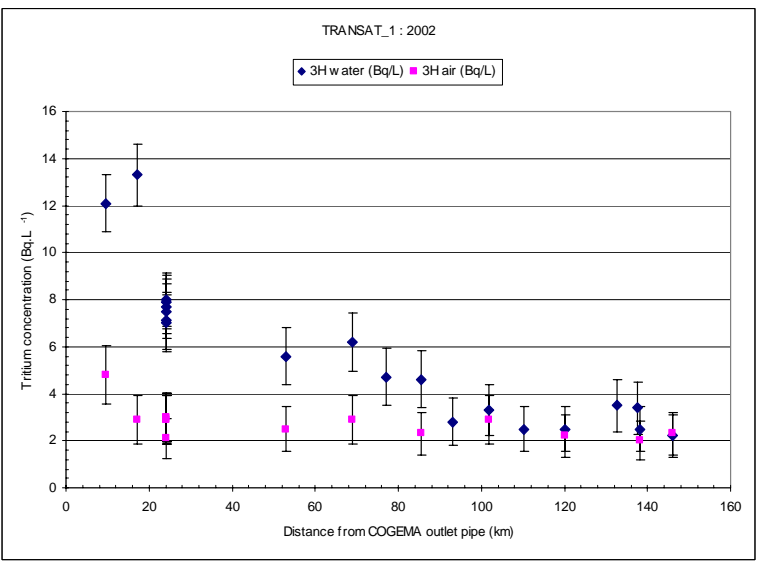

Figure 3. Variation of ${ }^{3} \mathrm{H}$ activities (Bq. $\mathrm{L}^{-1}$ ) in surface seawater and air versus distance from COGEMA outlet pipe during TRANSAT 1 cruise.

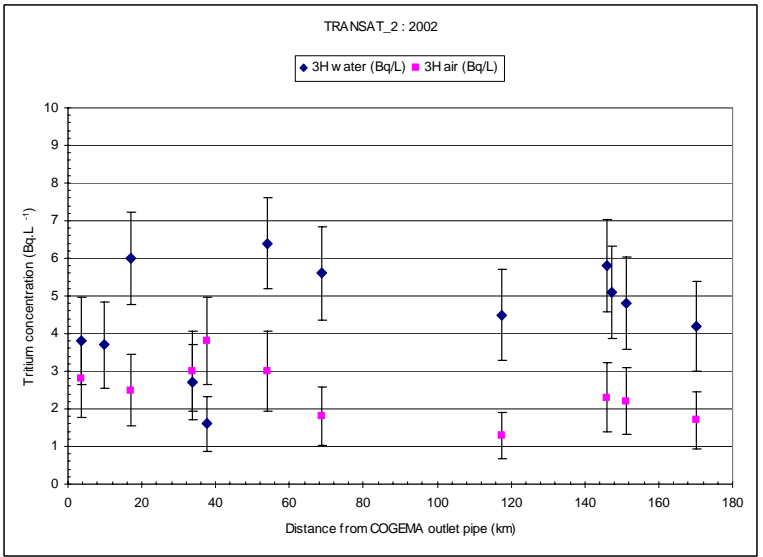

Figure 4. Variation of ${ }^{3} \mathrm{H}$ activities (Bq. $\mathrm{L}^{-1}$ ) in surface seawater and air versus distance from COGEMA outlet pipe during TRANSAT 2 cruise. 


\subsection{Flux of ${ }^{3} \mathrm{H}$ between water and atmosphere}

The water vapour and ${ }^{3} \mathrm{H}$ flux determined during the TE-SEA, TRANSAT 1 and 2 cruises are given in figures 5 to 7.

The mean water vapour flux measurements obtained during these cruises was $2.710^{6} \mathrm{~kg} \cdot \mathrm{km}^{-2} \cdot \mathrm{d}^{-1}$ (TE-SEA), $3.210^{6} \mathrm{~kg} \cdot \mathrm{km}^{-2} \cdot \mathrm{d}^{-1}$ (TRANSAT 1) and $2.810^{6} \mathrm{~kg} \cdot \mathrm{km}^{-2} \cdot \mathrm{d}^{-1}$ (TRANSAT 2), corresponding to a mean flux of ${ }^{3} \mathrm{H}$ from water to atmosphere of $4.010^{7} \mathrm{~Bq} \cdot \mathrm{km}^{-2} \cdot \mathrm{d}^{-1}$ (TE-SEA), $2.010^{7} \mathrm{~Bq} \cdot \mathrm{km}^{-2} \cdot \mathrm{d}^{-1}$ (TRANSAT 1) and $1.310^{7} \mathrm{~Bq} \cdot \mathrm{km}^{-2} \cdot \mathrm{d}^{-1}$ (TRANSAT 2). Generally, ${ }^{3} \mathrm{H}$ flux between water and atmosphere falls with distance from the discharge point, reflecting the dilution of liquid waste in the Channel waters. The mean flux was slightly higher during TE-SEA in the area close to the COGEMA La Hague point of discharge into the sea. During TRANSAT 1 the mean flux was higher than during TRANSAT 2 because the windspeed was higher (factor 2). The mean flux calculated for all the cruises was $2.410^{7} \mathrm{~Bq} \cdot \mathrm{km}^{-2} . \mathrm{d}^{-1}$. Over an area corresponding to Seine Bay $\left(4400 \mathrm{~km}^{2}\right)$ the quantity of ${ }^{3} \mathrm{H}$ transferred into the atmosphere per year can be evaluated at $39 \mathrm{TBq}$ i.e. $0.3 \%$ of the quantity of ${ }^{3} \mathrm{H}$ discharged into the sea in 2002 by the COGEMA La Hague plant.

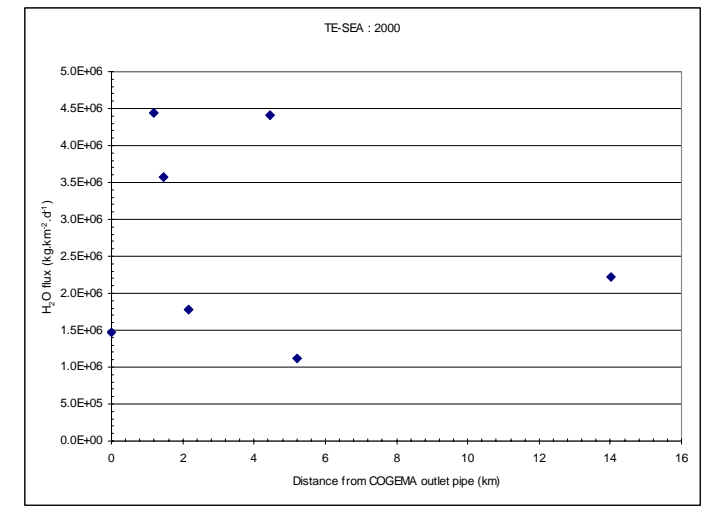

a)

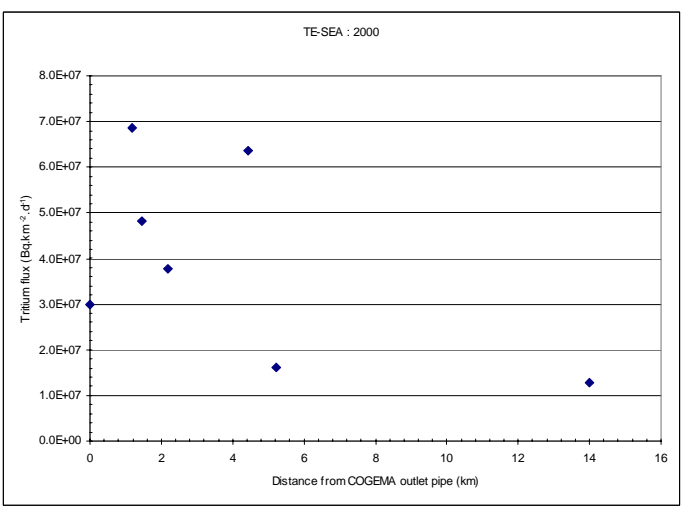

b)

Figure 5. Variation of water vapour fluxes (a) and ${ }^{3} \mathrm{H}$ fluxes (b) versus distance from COGEMA outlet pipe during TE-SEA cruise.

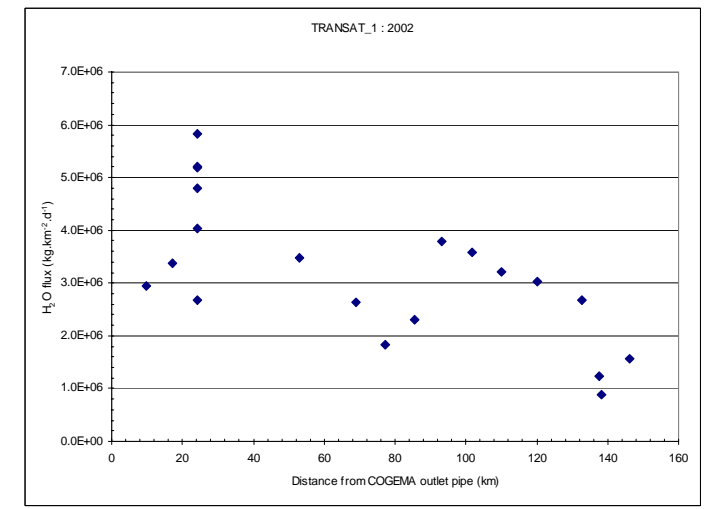

a)

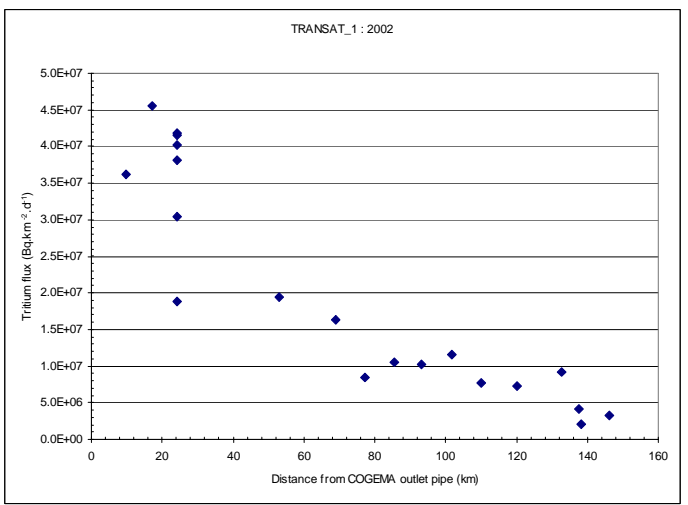

b)

Figure 6. Variation of water vapour fluxes (a) and ${ }^{3} \mathrm{H}$ fluxes (b) versus distance from COGEMA outlet pipe during TRANSAT 1 cruise. 


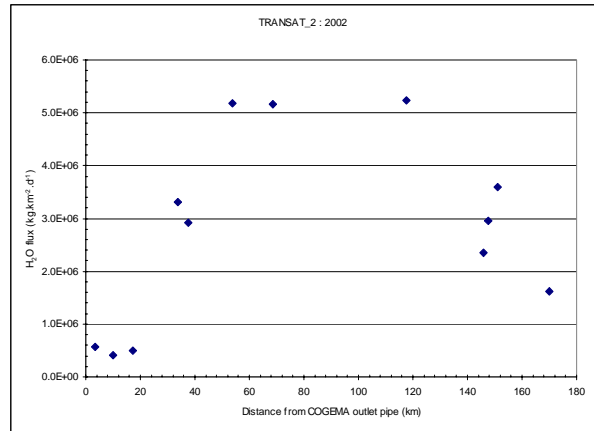

a)

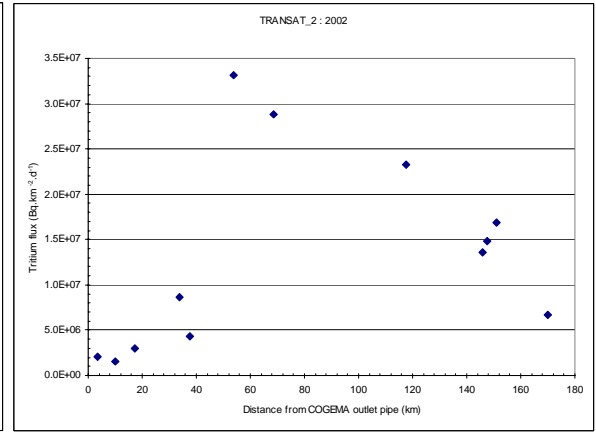

b)

Figure 7. Variation of water vapour fluxes (a) and ${ }^{3} \mathrm{H}$ fluxes (b) versus distance from COGEMA outlet pipe during TRANSAT 2 cruise.

\section{CONCLUSION}

The oceanographic cruises TE-SEA, TRANSAT 1 and 2 performed in the English Channel revealed atmospheric labelling with ${ }^{3} \mathrm{H}$ following the evaporation of seawater labelled with tritiated waste from the COGEMA La Hague spent fuel reprocessing plant. The mean flux of water vapour and ${ }^{3} \mathrm{H}$ between water and atmosphere was evaluated respectively at $2.910^{6} \mathrm{~kg} \cdot \mathrm{km}^{-2} \cdot \mathrm{d}^{-1}$ and $2.410^{7} \mathrm{~Bq} \cdot \mathrm{km}^{-2} \cdot \mathrm{d}^{-1}$, which corresponds an annual quantity of $39 \mathrm{TBq}$ transferred into the atmosphere by this process, i.e. $0.3 \%$ of the quantity of ${ }^{3} \mathrm{H}$ discharged into the sea in 2002 by COGEMA La Hague. This method must be generalised to provide a global estimate of the exchanges of ${ }^{3} \mathrm{H}$ between water and atmosphere for the whole of the English Channel.

\section{Acknowledgements}

The authors thank Messrs Le Bar and Schgier, Mrs Fitamant and her team at COGEMA for helping us during these cruises. We also thank Messrs Le Bourhis and Henri, captains of the CNRS oceanographic vessel "Côtes de La Manche" and their crews.

\section{References}

[1] Fontugne M., Maro D., Baron Y., Hatté C., Hébert D. and Douville E., Identification of sources and distribution of radiocarbon in the vicinity of La Hague nuclear reprocessing plant, Radioprotection 37, C1 (2002) 1271-1276.

[2] Maro D., Fontugne M., Hatté C., Hébert D. and Rozet M., ${ }^{14} \mathrm{C}$ sources and distribution in the vicinity of La Hague nuclear reprocessing plant: Part II-Marine environment, Radiocarbon 46, Nr 2 (2004), 831-839.

[3] Maro D., Germain P., Calmet D., Fournier M., Le tritium dans l'environnement proche du site de l'usine de retraitement de La Hague, Résultats des campagnes de prélèvements dans l'environnement marin et terrestre pour le district de La Hague, Rapport IPSN/DPRE/SERE 98/029 (1998), 17 p.

[4] Surveillance trimestrielle de l'environnement de La Hague, quatrième trimestre, Rapport HAG 006000320019 (2002), 63 p.

[5] Rohwer C., Evaporation from a free water surface, U.S. Dept. of Agr., Tech. Bull. (1931).

[6] Maro D., Germain P., Hebert D., Solier L., Rozet M., Leclerc G. and Le Cavelier S., Krypton 85: A tool for investigating near field atmospheric dispersion for elevated emissions around La Hague spent fuel nuclear reprocessing plant, 8Th Int. Conf. On Harmonisation within Atmospheric Dispersion Modelling for Regulatory purposes, Sofia, Bulgaria, 14-17 October 2002, E. Batchvarova and D. Syrakov Eds (2002), pp. 138-143.

[7] Bailly du Bois P., (pers. Comm). 